\title{
HUBUNGAN ANTARA KEMAMPUAN MENGENALI DIRI DAN KEMAMPUAN MENGONTROL DIRI TERHADAP INTENSI MENCONTEK MATA PELAJARAN FISIKA SISWA MA MADANI ALAUDDIN PAO-PAO KAB. GOWA
}

\author{
Imam Permana, Fitriani Kadir \\ UIN Alauddin Makassar, Universitas Muslim Maros \\ imam.permana922@gmail.com
}

\begin{abstract}
Relationship between the Ability to Know Yourself and Ability to Control Yourself with Intension Cheating Students MA Madani Alauddin Pao-Pao Kab. Gowa. This study aims to interpret the relationship between the ability to recognize themselves and the ability to control themselves with the intention of cheating physics subject MA Madani Alauddin Pao-Pao District. Gowa. The population is all students with Proportional Stratified Random Sampling techniques. The instrument used was a questionnaire. Data analysis techniques used are descriptive statistics and inferential statistics to test the hypothesis. Based on the results of research and descriptive analysis obtained an average score of students' self-recognition ability and ability to control themselves are in the sufficient category. As well as the average score of intention to cheat students' physics subjects in the medium category. The results of inferential analysis show the value of Fcount is 179.38 while the $\mathrm{F}$ table at a significance level of $5 \%$ is 3.26 . Thus, the value of Fcount is much greater than the value of Ftable then $\mathrm{Ha}$ is accepted, meaning that there is a negative and significant relationship between the ability to recognize oneself and the ability to control oneself with the intention of cheating physics students in the MA Madani Alauddin Pao-Pao District. Gowa.
\end{abstract}

\footnotetext{
Abstrak: Hubungan antara Kemampuan Mengenali Diri dan Kemampuan Mengontrol Diri dengan Intensi Mencontek Siswa MA Madani Alauddin Pao-Pao Kab. Gowa. Penelitian ini bertujuan untuk menginterpretasikan hubungan antara kemampuan mengenali diri dan kemampuan mengontrol diri dengan intensi mencontek mata pelajaran fisika siswa MA Madani Alauddin PaoPao Kab. Gowa. Populasinya adalah seluruh siswa dengan teknik sampel Proportional Stratified Random Sampling. Instrumen yang digunakan adalah angket. Teknik analisis data yang digunakan yaitu statistik deskriptif dan statistik inferensial untuk uji hipotesis. Berdasarkan hasil penelitian dan analisis deskriptif diperoleh skor rata-rata kemampuan mengenali diri siswa dan kemampuan mengontrol diri berada pada kategori cukup. Serta skor rata-rata intensi menyontek mata pelajaran fisika siswa berada pada kategori sedang. Adapun hasil analisis inferensial menunjukkan nilai $\mathrm{F}_{\text {hitung }}$ adalah 179,38 sedangkan $\mathrm{F}_{\text {tabel }}$ pada taraf signifikansi 5\% adalah 3,26. Dengan demikian, nilai Fhitung jauh lebih besar dari pada nilai Ftabel maka Ha diterima, artinya terdapat hubungan yang negatif dan signifikan antara kemampuan mengenali diri dan kemampuan mengontrol diri
} 
dengan intensi menyontek mata pelajaran fisika siswa MA Madani Alauddin PaoPao Kab. Gowa.

Kata kunci: intensi mencontek, mengenali diri, mengontrol diri

Kenyataan bahwa sistem pendidikan Indonesia yang menggunakan nilai dari tes atau evaluasi belajar terhadap materi yang diberikan sebelumnya untuk menunjukkan kemajuan dan penguasaan ilmu anak didik, menyebabkan masyarakat memandang prestasi belajar hanya dari pencapaian nilai yang tinggi, bukan pada prosesnya (Sujana dan Wulan, 1994: 2).

Kemungkinan kegagalan mencapai nilai yang tinggi diangggap sebagai ancaman dan merupakan stimulus yang tidak menyenangkan. Ada berbagai respons yang dilakukan siswa dalam menghadapi ancaman kegagalan, misalnya mempelajari materi secara teratur atau berlatih mengerjakan soal-soal latihan yang diberikan guru. Ada pula siswa yang memberikan respons menghindari ancaman kegagalan tersebut dengan mencontek. Perilaku mencontek bukan cara yang benar untuk memperoleh nilai tinggi (Gibson dalam Sujana dan Wulan, 2004: 1).

Perilaku mencontek menjadi masalah karena akan menimbulkan kekaburan dalam pengukuran kemampuan siswa, guru menjadi sulit untuk menentukan penilaian secara objektif. Menurut Indarto dan Masrun, Salah satu cara untuk membentuk konsep diri adalah dengan pengenalan diri. Pengenalan diri adalah kemampuan seseorang untuk melihat kekuatan dan kelemahan yang ada pada dirinya sehingga dapat melakukan respon yang tepat terhadap tuntutan yang muncul dari dalam maupun dari luar. Pengenalan diri ini dikatakan Noesjirwan dalam (Koentjoro,1989) merupakan langkah yang diperlukan orang untuk dapat menjalankan kehidupan ini secara efektif. Kekuatan-kekuatan yang ada pada diri merupakan aset dalam kehidupan sehari-hari, namun demikian apabila kekuatan-kekuatan itu tidak disadari maka kesempatan untuk mengaktualisasikan diri akan hilang. Demikian halnya dengan kelemahankelemahan yang ada pada diri seseorang. Kelemahan-kelemahan yang tidak disadari tidak hanya merugikan diri sendiri tetapi juga dapat menyusahkan orang lain. Ada orang yang terlalu percaya diri akan kemampuannya sementara orang lain menganggap kemampuannya biasabiasa saja.
Telah dijelaskan di atas bahwa faktorfaktor seseorang melakukan perilaku mencontek adalah tuntutan dari orang tua atau keinginan memperoleh nilai yang baik. Hal ini terkadang membuat keadaan emosi terganggu dipengaruhi sedemikian rupa hingga pada umumnya individu kurang dapat menguasai diri lagi. Perilakunya pada umumnya tidak lagi memperlihatkan suatu norma yang ada dalam hidup bersama. Namun demikian kadang-kadang orang masih dapat mengontrol keadaan dirinya sehingga emosi yang dialami tidak tercetus keluar dengan perubahan atau tanda-tanda kejasmanian (Walgito, 2010: 19). Dalam keadaan emosi Goldfried dan Merbaum(dalam Lazarus, 1976), mendefinisikan kontrol diri sebagai suatu kemampuan untuk menyusun, membimbing, mengatur dan mengarahkan bentuk perilaku yang dapat membawa individu ke arah konsekuensi positif. Kontrol diri merupakan suatu kecakapan individu dalam kepekaan membaca situasi diri dan lingkungannya serta kemampuan untuk mengontrol dan mengelola faktor-faktor perilaku sesuai dengan situasi dan kondisi untuk menampilkan diri dalam melakukan sosialisasi (Roosianti, 1994).

Berdasarkan uraian di atas, ditambah lagi dengan pengalaman penulis yang melihat secara langsung praktek mencontek di MA Madani Alauddin Pao-Pao Kab. Gowa sewaktu mengajar di sekolah tersebut, maka penulis tertarik untuk melakukan penelitian dengan judul "Hubungan antara Kemampuan Mengenali Diri dan Kemampuan Mengotrol Diri dengan Intensi Mencontek Mata Pelajaran Fisika Siswa MA Madani Alauddin Pao-Pao Kab. Gowa”.

Penelitian ini bertujuan untuk menginterpretasikan hubungan antara kemampuan mengenali diri dan kemampuan mengontrol diri dengan intensi mencontek mata pelajaran fisika siswa MA Madani Alauddin Pao-Pao Kab. Gowa.

\section{TINJAUAN PUSTAKA}

\section{Pengenalan Diri}

Pengenalan diri adalah kemampuan seseorang untuk melihat kekuatan dan 
kelemahan yang ada pada dirinya sehingga dapat melakukan respons yang tepat terhadap tuntutan yang muncul dari dalam maupun dari luar. Pengenalan diri ini dikatakan Noesjirwan (Koentjoro, 1989) merupakan langkah yang diperlukan orang untuk dapat menjalankan kehidupan ini secara efektif. Kekuatan-kekuatan yang ada pada diri merupakan aset dalam kehidupan sehari-hari, namun demikian apabila kekuatan-kekuatan itu tidak disadari maka kesempatan untuk mengaktualisasikan diri akan hilang. Demikian halnya dengan kelemahankelamahan yang ada pada diri seseorang. Kelemahan-kelamahan yang tidak disadari tidak hanya merugikan diri sendiri tetapi juga dapat menyusahkan orang lain. Ada orang yang terlalu percaya diri akan kemampuannya sementara orang lain menganggap kemampuannya biasabiasa saja.

\section{Kontrol Diri}

Menurut Chaplinkontrol diri adalah kemampuan untuk membimbing tingkah laku sendiri dalam artian kemampuan seseorang untuk menekan atau merintangi impuls-impuls atau tingkah laku impulsif (Caplin, 2002: 404). Kontrol diri ini menyangkut seberapa kuat seseorang memegang nilai dan kepercayaannya untuk dijadikan acuan ketika ia bertindak atau mengambil suatu keputusan.

Kontrol diri adalah individu-individu sebagai pengaturan proses-proses fisik, psikologis dan perilaku seseorang. Di mana kontrol diri ini penting untuk dikembangkan karena individu tidak hidup sendiri melainkan bagian dari kelompok masyarakat. Individu mempunyai kebutuhan untuk memuaskan keinginan dan kebutuhannya sehingga agar tidak mengganggu dan melanggar kenyamanan dan keselamatan orang lain, individu harus mengontol perilakunya. Kedua, masyarakat menghargai kemampuan, kebaikan yang dimiliki individu sehingga dapat diterima masyarakat lainnya (Calhoun \& Acocella, 1990).

Lazaruz (1976) mengatakan bahwa kontrol diri menggambarkan keputusan individu yang melalui pertimbangan kognitifnya untuk menyatakan perilaku yang telah disusun untuk meningkatkan hasil dan tujuan tertentu seperti apa yang dikehendaki. Hal ini berarti kontrol diri untuk memahami keseluruhan khazanah pengungkapan diri baik yang positif maupun negatif sehingga individu menyadari apa yang bisa membangkitkan ekspresi-ekspresi positif maupun negatif di dalam dirinya. Jika individu mampu menghindari situasi-situasi yang dapat memicu sifat-sifat negatif berarti individu tidak membiarkan diri menyerah pada kecenderungankecenderungan untuk bereaksi secara negatif ketika individu menghadapi realitas keras dalam hidupnya (Lazarus, 1976: 221).

Lebih lanjut Calhoun \& Acocellamemandang bahwa individu dalam mengontrol perilaku melibatkan tiga hal yaitu, pertama, memilih dengan sengaja; kedua, pilihan antara dua perilaku yang bertentangan, dalam artian satu pihak perilaku menawarkan kepuasan dengan segera, sedangkan perilaku yang lain menawarkan ganjaran jangka panjang; ketiga, memanipulasi stimulus, agar satu perilaku yang kurang mungkin dilakukan dapat dilakukan dengan perilaku lain yang lebih mungkin dilakukan (http://www.damandiri.or.id diakses tanggal 12 September 2013).

\section{Intensi Mencontek}

Belum ada teori yang menjelaskan mengenai intensi mencontek, sehingga definisi intensi mencontek diperoleh dari definisi intensi dan definisi mencontek. Secara sederhana, intensi dapat diartikan sebagai tujuan atau maksud seseorang untuk berbuat sesuatu (Kartono dan Gulo, 1987: 26). Intensi diartikan sebagai niat seseorang untuk melakukan perilaku didasari oleh sikap dan norma subjektif terhadap perilaku tersebut. Norma subjektif muncul dari keyakinan normatif akan akibat perilaku, dan keyakinan normatif akibat perilaku tersebut terbentuk dari umpan balik yang diberikan oleh perilaku itu sendiri (Fishbein dan Ajzen, 1975: 288). Fishbein dan Ajzen menambahkan bahwa intensi perilaku merupakan determinan terdekat dengan perilaku yang dimaksud dan merupakan prediktor tunggal terbaik bagi perilaku yang akan dilakukan seseorang. Sependapat dengan pernyataan tersebut, Semin dan Fiedler (1996:17) menyatakan bahwa prediksi terhadap perilaku paling tepat diperoleh dengan mengukur intensi.

Intensi juga dapat didefinisikan sebagai maksud, pamrih, keinginan, tujuan, suatu perjuangan guna mencapai satu tujuan, ciri-ciri yang dapat dibedakan dari proses-proses psikologi, yang mencakup referensi atau 
kaitannya dengan suatu objek (Chaplin, 1999: 254).

Berdasarkan uraian mengenai berbagai definisi intensi di atas, dapat disimpulkan bahwa intensi adalah niat atau keinginan seseorang untuk melakukan suatu perilaku demi mencapai tujuan tertentu yang didasarkan pada sikap dan keyakinan orang tersebut maupun keyakinan dan sikap orang yang memengaruhinya untuk melakukan suatu perilaku tertentu.

Intensi yang akan diukur dalam penelitian ini adalah intensi untuk melakukan perilaku menyontek. Menurut Sujana dan Wulan (1994: 1) menyontek merupakan tindakan kecurangan dalam tes melalui pemanfaatan informasi yang berasal dari luar secara tidak sah. Mencontek juga dapat didefinisikan sebagai perbuatan curang, tidak jujur, dan tidak legal dalam mendapatkan jawaban pada saat tes (Indarto dan Masrun, 2004: 411). Sependapat dengan kedua definisi di atas, Haryono, dkk (2001: 10) mendefinisikan mencontek sebagai segala macam tindakan dalam ujian atau tes untuk memperoleh nilai secara tidak sah. Dengan demikian, mencontek dapat diartikan sebagai segala macan perbuatan curang, tidak, jujur, dan tidak legal untuk mendapatkan jawaban pada saat tes untuk memperoleh nilai secara tidak sah dengan memanfaatkan informasi dari luar.

Berdasarkan definsi intensi dan definisi mencontek yang diuraikan di atas, maka intensi menyontek didefiniskan sebagai niat atau keinginan seseorang untuk melakukan perbuatan curang, tidak, jujur, dan tidak legal untuk mendapatkan jawaban pada saat tes untuk memperoleh nilai secara tidak sah dengan memanfaatkan informasi dari luar, berdasar pada sikap dan keyakinan orang tersebut maupun sikap dan keyakinan orang lain yang memengaruhinya mengenai perilaku menyontek.
Jenis penelitian yang digunakan yaitu penelitian research kuantitatif dengan desain deskriptif korelasional yang bertujuan untuk melihat bagaimana variasi-variasi pada suatu faktor berkaitan dengan variasi-variasi faktor lain berdasarkan pada koefisien korelasi. Adapun desain penelitian sebagai berikut:

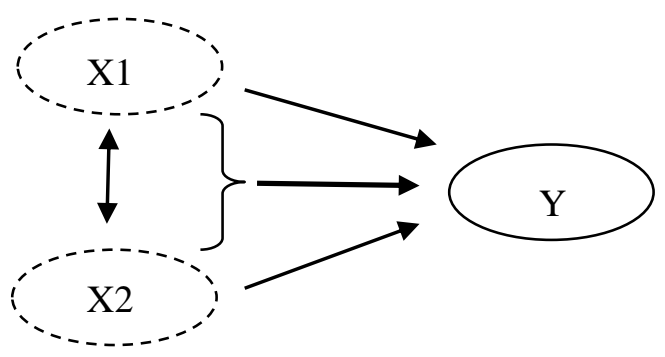

Keterangan :

$\mathrm{X} 1=$ Kemampuan mengenali diri

$\mathrm{X} 2=$ Kemampuan mengontrol diri

$\mathrm{Y}=$ Intensi mencontek mata pelajaran fisika

(Sumadi Suryabrata, 2011: 82)

Populasi dalam penelitian ini adalah seluruh siswa MA Madani Alauddin Pao-Pao Kab. Gowa yang masih aktif dengan jumlah 121 siswa (kelas X, Kelas XI, dan Kelas XII). teknik sampling yang digunakan Proportional Stratified Random Sampling,adapun penjelasannya adalah:

a. Proporsional sampling adalah sampel pembagian secara representatif, dimana peneliti hanya bisa mengambil $30 \%$ dari populasi yang ada (361 siswa) yaitu $20 \% \mathrm{x}$ 361 siswa $=36,3$ atau 36 mahasiswa dengan tujuan agar semua populasi terwakili.

b. Stratified adalah pengambilan sampel berdasarkan tingkatan kelas.

c. Random adalah pengambilan sampel secara acak. Untuk lebih jelasnya dapat dilihat pada tabel berikut ini.

\section{METODE}

Tabel 1 Tabel Distribusi Sampel

\begin{tabular}{cccc}
\hline Angkatan & Jumlah kelas & Jumlah siswa(i) & Sampel \\
\hline X & 2 & 52 & $15,6 \approx 16$ \\
\hline XI IPA & 1 & 31 & $9,3 \approx 9$ \\
\hline XII IPA & 2 & 38 & $11,4 \approx 11$ \\
\hline Jumlah & $\sum 5$ & $\sum 121$ & $\sum 36$ \\
\hline
\end{tabular}


Instrumen yang digunakan adalah kuisioner dengan teknik analisis deskriftif product moment berganda pada taraf signifikansi 5\%.

\section{HASIL DAN PEMBAHASAN}

\section{Kemampuan mengenali diri}

Berdasarkan pengolahan data yang telah dilakukan, dimana jumlah sampel yang diteliti adalah 36 orang yang mewakili tiap tingkatan kelas. Diperoleh data dari pengolahan statistik deskriptif maka peneliti dapat menyimpulkan bahwa kemampuan mengenali diri siswa MA Madani Alauddin Pao-Pao Kab. Gowa berada pada kategori tinggi berdasarkan dari nilai ratarata yang diperoleh yakni 90,19. Ini menandakan bahwa mereka sudah mampu mengenali fisik dan psikologis mereka hingga akhirnya mampu memberikan respon yang tepat untuk setiap masalah yang dihadapi.

\section{Kemampuan mengontrol diri}

Berdasarkan hasil analisis data dengan menggunakan statistik deskriptif dan berdasarkan nilai hasil perhitungan rata-rata (mean) dari data yang telah disajikan, maka pbuenulis bisa mengambil kesimpulan bahwa kemampuan mengontrol diri siswa MA Madani Alauddin Pao-Pao Kab. Gowa berada pada kategori tinggi berdasarkan dari nilai rata-rata yang diperoleh yakni 86,67.Ini menandakan bahwa mereka sudah mampu mengontrol tingkah laku yang pada akhirnya akan membawa mereka kea rah yang positif.

\section{Intensi mencontek pada mata pelajaran fisika}

Sementara itu, berdasarkan hasil analisis data dengan menggunakan statistik deskriptif dan berdasarkan nilai hasil perhitungan rata-rata (Mean) dari data yang telah disajikan, maka penulis bisa mengambil kesimpulan bahwa intensi mencontek pada mata pelajaran fisikasiswa MA Madani Alauddin Pao-Pao Kab. Gowa berada pada kategori sedang berdasarkan dari nilai rata-rata yang diperoleh yakni 57,25.Ini menandakan bahwa intensi mereka untuk membuat catatan dan mencontek jawaban teman masih sedang, kadang mengkhawatirkan dan kadang pula tidak. Peran guru dan orang tua sangat diperlukan untuk mengatasi hal ini.

\section{Hubungan kemampuan mengenali diri dengan intensi mencontek mata pelajaran fisika}

Berdasarkan analisis data dengan menggunakan statistik inferensial, diperoleh $\mathrm{r}_{\text {hitung }}$ adalah 0,983 data tersebut menginformasikan bahwa kedua variabel ini memiliki hubungan yang sangat kuat. Setelah $\mathrm{r}_{\text {hitung }}$ diperoleh, peneliti membandingkan antara $r_{\text {hitung }}$ dan $r_{\text {tabel }}$ untuk menguji hipotesis dengan taraf signifikan yang digunakan adalah $5 \%$, ternyata data yang diperoleh $\mathrm{r}_{\text {hitung }}$ lebih besar di bandingkan dengan $r_{\text {tabel}}$, dimana $r_{\text {tabel }}$ yang diperoleh adalah 0,235. Dengan demikian peneliti dapat menyimpulkan bahwa terdapat hubungan yang negatif dan signifikan antara kemampuan mengenali diri dengan intensi mencontek mata pelajaran fisika siswa MA Madani Alauddin Pao-Pao Kab. Gowa . Dengan kata lain $\mathrm{H}_{\mathrm{a}} 1$ diterima.

Hal ini juga dilihat dari kontribusi variabel dependennya yang sangat besar yakni sebesar 96,6\%, yang berarti kontribusi variabel kemampuan mengenali diri sangat besar terhadap intensi mencontek mata pelajaran fisika siswa MA Madani Alauddin Pao-Pao Kab. Gowa, dimana semakin tinggi dan selebihnya $3,34 \%$ dipengaruhi oleh faktor-faktor lain. Perilaku dan gejala perilaku dipengaruhi baik oleh faktor internal dan lingkungan. Secara umum dapat dikatakan bahwa faktor internal dan lingkungan ini merupakan penentu dari perilaku manusia (Walgito, 2003:1).

\section{Hubungan antara kemampuan mengontrol diri dengan intensi mencontek mata pelajaran fisika}

Berdasarkan analisis data dengan menggunakan statistik inferensial diperoleh data untuk $\mathrm{r}_{\text {hitung }}$ adalah 0,984 yang berarti kedua variabel ini memiliki hubungan yang sangat kuat. Selanjutnya dengan taraf signifikan yang sama yakni $5 \%$ dapat diketahui bahwa $\mathrm{r}$ hitung lebih besar dibandingkan dengan $r_{\text {tabel }}(0,993 \geq$ $0,329)$ yang mana hal ini bertujuan untuk pengujian hipotesis. Dengan demikian, dapat disimpulkan bahwa terdapat terdapat hubungan yang negatif dan signifikan antara kemampuan mengenali diri dengan intensi mencontek pada 
mata pelajaran fisika siswa MA Madani Alauddin Pao-Pao Kab. Gowa. Artinya $\mathrm{H}_{\mathrm{a}} 2$ diterima dan $\mathrm{H}_{0} 2$ ditolak.

Hal ini juga dilihat dari kontribusi veriabel dependennya yang sangat besar yakni sebesar $96,8 \%$, yang berarti kontribusi varibel kemampuan mengenali diri dengan intensi menyontek pada mata pelajaran fisikasiswa MA Madani Alauddin Pao-Pao Kab. Gowa, dan selebihnya 3,32\% dipengaruhi oleh faktor-faktor lain. Diantaranya adalah pengaruh lingkungan.

Teori skinner yang beranggapan bahwa manusia mampu melakukan tindakan-tindakan atas inisiatif sendiri dalam lingkungannya, bukan sebagai objek dan relatif (Farosin, 2003: 11).

\section{Hubungan antara kemampuan mengenali diri dengan kemampuan mengontrol diri}

Dengan analisis data yang sama yakni statistik inferensial, peneliti memperoleh data untuk $r_{\text {hitung }}$ yaitu 0,995 , hal ini berarti kemampuan mengenali diri dan kemampuan mengontrol diri memilki hubungan yang kuat. Kemudian untuk menguji hipotesis peneliti membandingkan antara $r_{\text {hitung }}$ dan $r_{\text {tabel }}$. Dengan taraf signifikansi $5 \%$ peneliti memperoleh nilai $\mathrm{r}_{\text {tabel }}$ yaitu 0,329.

Dengan demikian peneliti dapat menyimpulkan bahwa terdapat hubungan yang positif dan signifikan antara kemampuan mengenali diri dengan kemampuan mengontrol diri siswa MA Madani Alauddin Pao-Pao Kab. Gowa.

Menurut Mayer kesadaran diri adalah waspada terhadap suasana hati maupun pikiran tentang suasana hati, bila kurang waspada maka individu menjadi mudah larut dalam aliran emosi dan dikuasai oleh emosi. Kesadaran diri memang belum menjamin penguasaan emosi, namun merupakan salah satu prasyarat penting untuk mengendalikan emosi sehingga individu mudah menguasai emosi (Goleman, 1991: 64). Hal ini juga dilihat dari kontribusi variabel dependennya yang sangat besar yakni sebesar $99,0 \%$, yang berarti salah satu variabel yang dapat mendukung kemampuan mengelola emosi adalah kemampuan mengenali emosi diri, dan selebihnya $1,00 \%$ dipengaruhi oleh faktor-faktor lain.
Hubungan antara kemampuan mengenali diri dan kemampuan mengontrol diri terhadap intensi mencontek mata pelajaran fisika.

Berdasarkan analisis data dengan menggunakan analisis statistic inferensial yaitu product moment berganda diperoleh $\mathrm{r}_{\text {hitung }}$ yaitu 0,957 yang menandakan ketiga variable ini memiliki hubungan yang sangat kuat. Data yang diperoleh tersebut hanya berlaku untuk sampel yang diteliti, kemudian peneliti melakukan uji signifikan untuk memberlakukan nilai korelasi ke semua populasi yang mana diperoleh data Fhitung179,58. Setelah diperoleh data tersebut, peneliti melakukan uji hipotesis dengan membandingkan $F_{\text {hitung }}$ dan $F_{\text {tabel }}$. Dengan menggunakan $\mathrm{dk}$ pembilang $=2$ dan taraf kesalahan $5 \%$ peneliti memperoleh nilai $\mathrm{F}_{\text {tabel }}$ 3,26 . Dengan demikian diperoleh nilai $F_{\text {hitung }} \geq$ $\mathrm{Ft}_{\text {abel }}$, yang berarti $\mathrm{H}_{\mathrm{a}} 4$ diterima, dengan kata lain terdapat terdapat hubungan yang negatif dan signifikan antara kemampuan mengenali diri dan kemampuan mengontrl diri terhadapintensi mencontek mata pelajaran fisika siswa MA Madani Alauddin Pao-Pao Kab. Gowa .

Berdasarkan uraian di atas dapat disimpulkan bahwa semakin tinggi kemampuan mengenali diri dan kemampuan mengontrol diri seseorang maka intensi menyontek pada mata pelajaran fisika yang muncul akan rendah. Hal ini juga dilihat dari kontribusi kedua variabel dependennya yang sangat besar yakni sebesar $91,6 \%$, yang berarti kontribusi kemampuan mengenali diri dengan intensi menyontek mata pelajaran fisika siswa MA Madani Alauddin Pao-Pao Kab. Gowa. dan selebihnya 8,40\% dipengaruhi oleh faktor-faktor lain.

Sebuah laporan dari National Center For Clinical Programs (1992) Menyatakan bahwa keberhasilan disekolah bukan diramalkan oleh kumpulan fakta seorang siswa atau kemampuan dirinya untuk membaca, melainkan oleh ukuranukuran emosional dan sosial: yakni pada diri sendiri dan mempunyai minat; tahu pola perilaku yang diharapkan orang lain dan bagaimana mengendalikan dorongan hati untuk berbuat nakal; mampu menunggu, mengikuti petunjuk dan mengacu pada guru untuk mencari bantuan; serta mengungkapkan kebutuhankebutuhan saat bergaul dengan siswa lain. Hampir semua siswa yang prestasi sekolahnya buruk, menurut laporan tersebut, tidak memiliki 
satu atau lebih unsur-unsur kecerdasan emosional ini (tanpa memperdulikan apakah mereka juga mempunyai kesulitan-kesulitan kognitif) (Goleman, 1991: 65).

\section{PENUTUP}

Berdasarkan pengolahan data yang telah dilakukan, maka peneliti dapat menarik kesimpulan sebagai berikut:

1. Terdapat hubungan yang sangat kuat antara kemampuan mengenali diri dengan intensi menyontek pada mata pelajaran fisika siswa MA Madani Alauddin Pao-Pao Kab. Gowa, dimana nilai yang $r_{\text {hitung }}$ yang diperoleh yaitu 0,983 dan nilai korelasi yang diperoleh dapat diberlaukan untuk semua populasi.

2. Terdapat hubungan yang sangat kuat antara kemampuan mengontrol diri dengan intensi menyontek pada mata pelajaran fisika siswa MA Madani Alauddin Pao-Pao Kab. Gowa, dimana nilai yang $r_{\text {hitung }}$ yang diperoleh yaitu 0,984 dan nilai korelasi yang diperoleh dapat diberlaukan untuk semua populasi.

3. Terdapat hubungan yang sangat kuat antara kemampuan mengenali diri dengan kemampuan mengontrol diri siswa MA Madani Alauddin Pao-Pao Kab. Gowa, dimana nilai yang $r_{\text {hitung }}$ yang diperoleh yaitu 0,995 dan nilai korelasi yang diperoleh dapat diberlaukan untuk semua populasi.

4. Terdapat hubungan yang sangat kuat antara kemampuan mengenali diri dan kemampuan mengontrol diri terhadap intensi menyontek siswa MA Madani Alauddin Pao-Pao Kab. Gowa, dimana nilai yang rhitung yang diperoleh yaitu 0,916 dan nilai korelasi yang diperoleh dapat diberlaukan untuk semua populasi.

\section{DAFTAR PUSTAKA}

Arikunto, Suharsimi. 2010. Menejemen Penelitian; Jakarta: Rineka Cipta.

Ajzen, I. 1991. Attitude, Personality, and Behavior. Buchingham: OpenUniversity Press.

Alhadza, A. 1998. Masalah Menyontek (Cheating) di Dunia Pendidikan.
http://www.depdiknas.go.id/Jurnal/38/MASA LAH_MENYONTEK.htm

Anderman, E. M., Griesinger,T., dan Westerfield, G. 1998. Motivation andCheating During Early Adolescence. Journal of Educational Psychology.90, 1, 84-93.

Anonim.2013.DefinisiKontrolDiri.http://www.psych ologymania.com/2013/04/def inisi-kontroldiri.html

Arif Tiro, Muhammad. 2000. Dasar-dasar Statistika Edisi Revisi. Makassar: Universitas Negeri Makassar.

Baron, R. A., dan Byrne, D. 2003. Psikologi Sosial Jilid 2. Edisi 10.

Penerjemah:Ratna Juwita. Jakarta: Penerbit Erlanggga.

Bachri, Syamsul, T. 2010. Psikologi Pendidikan Berbasis Analisis Empiris Aplikatif. Jakarta: Kencana.

Brigham, J. C. 1991. Social Psychology. New York : Harper Collins Publisher.

Burns, R. B. 1993. Konsep Diri (Teori, Pengukuran, Perkembangan, danPerilaku). Alih bahasa: Eddy. Jakarta : Arcan.

Chaplin, J.P. 1999. Kamus Lengkap Psikologi. Jakarta : PT. Raja GrafindoPersada.

Caplin, J. P. 2002. Kamus Lengkap Psikologi. Jakarta: PT. Raja Grafindo Persada.

Carlson, N. R. (1987). The Science of Behavior. Boston: Allyn and Bacon a Division of Simon and Schusster Inc.

Departemen Pendidikan Nasional Indonesia. 2005. Peraturan PemerintahRepublik Indonesia Nomor 19 Tahun 2005 tentang Standar NasionalPendidikan.http://www.unissula.ac.id /v1/download/Peraturan/PP _19_2005_STANDAR_NAS_PENDDKN.PD F.

Depag. 2007. Al-Qur'an dan Terjemahan. Bandung: CV. Diponegoro.

Direktorat Jenderal Pendidikan Dasar dan Menengah Departemen Pendidikan danKebudayaan. 2006. Undang-undang Republik Indonesia 
Nomor

Tahun1989tentangSistemPendidikanNasional. http://www.dikti.org/uu_no 2_1989.htm.

Faturrohman.2012.PengendalianDiridalamPerspektif Islam.http://muhfathurrohman.wordpress.com /2012/10/12/pengendalian-dalam-perspektifislam/

Fishbein, M., dan Ajzen, I. 1975. Belief, Attitude, Intention and Behavior: AnIntroduction to Theory and Research. California: AddisonWesleyPublishing.

Gassing, Qadir dan Wahyuddin Alim. Pedoman Penulisan Karya Tulis Ilmiah Makalah,Skripsi, Tesis, dan Disertasi. Cet. Kedua. Makassar: Alauddin Press, 2009.

Goleman, Daniel. (2000). Emitional Intelligence (terjemahan). Jakata : PT Gramedia Pustaka Utama.

Goleman, Daniel. (2000). Working With Emotional Intelligence (terjemahan). Jakarta : PT. Gramedia Pustaka Utama.

Haryono, W., Hardjanta, G., dan Eriyani ,P. 2001. Perilaku Menyontek Ditinjaudari Persepsi terhadap Intensitas Kompetisi dalam Kelas dan

KebutuhanBerprestasi. Psikodimensia. Kajian Imiah Psikologi, 2, 1, 10-16.Grinder, A. 1978. Adolescence. New York : John willey \& Sons.

Higgins, J. M. 1982. Human Relations. Concept and Skills. New York : Random House Inc. http://acupofcoffeee.blog.com/2012/10/19/pen gendalian-diri/

Indarto, Y., dan Masrun. 2004. Hubungan Antara Orientasi Pguasaan danOrientasi Performansi dengan Intensi Menyontek. Jakarta: Sosiosains.

Johnson, D. W. \& Johnson, J. P. 1991. Joining Together. Group Theory and group Skill. Fourth edition. New York : Perntice-Hall, Inc.

Johnson, D. W. 1993 Reaching Out : Interpersonal Efffeciveness and Self-Actualization. Boston : Allyn and Bacon.

Kartono, K., dan Gulo, D. 1987. Kamus Psikologi. Bandung: CV. Pionir Jaya.
Klausmeier, H.J. 1985. Educational Psychology. New York: Harper and RowPublisher. Fifth Edition.

Koentjoro. 1989. Konsep Pengenalan diri dalam AMT. Makalah. Dalam Modul Pelatihan AMT. Jurusan Psikologi Social UGM, dalam rangka Lustrum V Fak. Psikologi UGM Yogyakarta.

Lazarus, R. S. (1976). Pattern of adjusment and human effectiveness. Tokyo: McGrawhill Kogausha.

Mamiye,Ryzka.2012.MencuridalamSyariatIslam.http ://zkamiye.blogspot.com/20 12/08/contohmakalah-kerajaan-bali_27.html

Mencontek, LangkahPertama Menjadi Koruptor (2006, 9 Septrember). SuaraMerdeka, hal 18.

Mulyana.2002.Nyontek:Budaya...?www.magazines wara1nyontek1/artikel2(19-12-2002).

Muljadi,L.2006.Nyontek:alaGaptekTatek.http://www .ranesi.nl/tema/kamera_nyon tek060203.

Poedjinoegroho, B. (2005, 7 Januari). Biasa Mencontek Melahirkan Koruptor.Kompas, hal 49.

Pudjijogjanti, C. R. 1985. Konsep Diri dalam Proses Belajar Mengajar. Jakarta:Pusat Penelitian Unika Atmajaya.

Rifan,Hakim.2013.HaditshaditsTentangKontrolDiri.h ttp://hakimachmadrifan.blogspot.com/2013/07 hadist-hadist-tentang-kontrol-diri.html

Sarwono, S.W. 1997. Psikologi Sosial. Individu dan Teori-teori Psikologi Sosial.Jakarta: Balai Pustaka.

Semin, G. R., dan Fiedler, K. 1996. Applied Social Psychology. London : SagePublications.

Slameto, 2010. Belajar dan Faktor-faktor Yang Mempengaruhinya. Jakarta:mRineka Cipta

Smet, B. 1994. Psikologi Kesehatan. Jakarta : Grasindo.

Soemanto, W. 1998. Landasan Kerja Pemimpin Pendidikan. Jakarta: PT RinekaCipta. 
Karst : Jurnal Pendidikan Fisika dan Terapannya

Volume 3 | Nomor 1 | 26 p-ISSN: 2622-9641 e-ISSN: 2655-1276

Sudijono, Anas. PengantarStatistik Pendidikan. Jakarta: PT Raja Grafindo, 2009.

Sugiyono. Metode Penelitian Pendidikan; Cet. Keenam. Bandung: Alfabeta. 2008.

Sugiyono. Memahami Penelitian Kualitatif. Bandung: Alfabeta, 2010.

Sugiyono. Statistik untuk Pendidikan; Cet. Ke-XVII. Bandung: Alfabeta, 2010.

Sujana, Y.E., dan Wulan, R. 1994. Hubungan Antara Kecenderungan PusatKendali dengan Intensi Menyontek. Semarang:Jurnal Psikologi.
Suryabrata, Sumadi. Psikologi Kepribadian;Edisi I. Jakarta: PT Raja Grafindo Persada, 2008.

Susana, T. 2006. Konsep Diri: Apakah Itu?. Konsep Diri Positif, MenentukanPrestasi Anak. Hal 17-23. Yogyakarta: Kanisius.

Syah, Muhibbin. Psikologi Belajar. Jakarta: PT Raja Grafindo Persada, 2008.

Tim Penulis. Psikologi belajar, Edisi I. Surabaya: Amanah Pustaka, 2009.

Tim Penyusun Kamus. Kamus Besar Bahasa Indonesia. Jakarta: Balai Pustaka, 1990.

Walgito, Bimo. 2003. Pengantar Psikologi Umum. Yogyakarta:

Penerbit

ANDI. 